\title{
EXPRESSION OF RESISTANCE IN RICE HYBRIDS TO Pyricularia grisea
}

\author{
ANNE S. PRABHU ${ }^{1}$, ELCIO P. GUIMARÃES ${ }^{1}$, MARTA C. FILIPPI', \\ LEILA G. ARAUJO² \& VERIDIANO A. CUTRIM ${ }^{1}$ \\ 'Embrapa Arroz e Feijão, Cx. Postal 179, CEP 75375-000, Santo Antônio de Goiás, GO, Fax (062) 533-2172, \\ e-mail: prabhu@cnpaf.embrapa.br; ${ }^{2}$ Escola de Agronomia, Universidade Federal de Goiás, \\ Cx. Postal 131, CEP 74001-970, Goiânia, GO, e-mail: leilag@enpaf.embrapa.br
}

(Accepted for publication on 02/07/2002)

Corresponding author: Anne S. Prabhu

PRABHU, A.S., GUIMÃRES, E.P., FILIPPI, M.C., ARAUJO, L.G. \& CUTRIM, V. dos A. Expression of resistance in rice hybrids to Pyricularia grisea. Fitopatologia Brasileira 27:454-460. 2002.

\begin{abstract}
Thirty-nine rice (Oryza sativa) hybrids and their restorers were assessed for vertical resistance to Pyricularia grisea in the rice blast nursery, and in artificial inoculation tests with two pathotypes, under controlled greenhouse conditions. The hybrids were developed from cytoplasmic genetic male sterile lines 046I and IR 58025A, derived from WA cytoplasm. In the rice blast nursery all hybrids showed susceptible reaction varying from 5 to 9. Compatible and incompatible leaf blast reactions of hybrids to two pathotypes, IC-1 and IB-45, were observed in inoculation tests. A majority of the hybrids were resistant when the restorer

was resistant. However, seven of the $25 \mathrm{~F}_{1}$ hybrids exhibited susceptible reactions even when one of the parents was resistant to a pathotype. The partial resistance of 11 hybrids and their parents that showed compatible reactions to two pathotypes was analyzed. Differential interaction between isolates and genotypes was observed for partial resistance in relation to both disease severity and lesion number indicating the specific nature of partial resistance.

Additional key words: Magnaporthe grisea, rice blast, hybrid rice, partial resistance, Oryza sativa.

\section{RESUMO}

\section{Expressão de resistência em híbridos de arroz a Pyricularia grisea}

Foram avaliados 39 híbridos de arroz (Oryza sativa) desenvolvidos a partir das linhagens 046I e IR 58025A com macho esterilidade genético citoplasmática derivado do citoplasma WA e seus restauradores, para resistência vertical a Pyricularia grisea. Os testes foram realizados em viveiro de brusone e em condições artificiais de inoculação com dois patotipos, em casa de vegetação. Em viveiro de brusone, todos os híbridos apresentaram reação suscetível variando de 5 a 9 em uma escala de 0 a 9 . Reações compatíveis e incompatíveis à brusone nas folhas foram observadas para

os dois patotipos IC-1 e IB-45, em inoculações controladas. A maioria dos híbridos foi resistente quando o restaurador utilizado como pai foi resistente. Entretanto, sete dos 25 híbridos $\mathrm{F}_{1}$ apresentaram reação suscetível mesmo quando um dos pais foi resistente para um patótipo. A resistência parcial de 11 híbridos e seus pais que apresentaram reação compatível foi analisada para resistência parcial. Foi observada interação diferencial entre isolados e genótipos para resistência parcial em relação a severidade e número de lesões esporulativas, indicando a natureza especifica da resistência parcial.
\end{abstract}

\section{INTRODUCTION}

Hybrid rice (Oryza sativa L.) production considered one of the alternatives to improving the average yield of irrigated rice in Brazil, which has remained stagnant in the last decade (Guimarães et al., 1998). In China, hybrid rice occupies approximately 17 million hectares corresponding to $55 \%$ of the total rice area planted (Mao et al., 1998). The yields of hybrids have shown to be $30 \%$ greater than commercial rice cultivars developed by conventional breeding methods (Yuan et al., 1994).

In Brazil, collaborative research on hybrid rice began in 1984 between Embrapa Rice \& Beans and the Center for International Cooperation on Research in Agricultural

*Bolsista do CNPq,
Development (CIRAD). This research has accumulated a large quantity of information (Guimarães et al., 1998). Among male sterility systems, the cytoplasmic male sterile lines (CMS) derived from a wild rice Oryza sativa f. spontanea L. (WA) has been found to be most effective and practical in different parts of the world. The allogamic trait from the wild species $O$. longistaminata A. Chev with large stigma was transferred to the genetic background of the cultivated species O. sativa (Tallebois, 1983). A CMS line 046I with allogamic traits and desirable agronomic characteristics was developed in research conducted at Embrapa Rice \& Beans, Goiânia, Goiás (Tallebois \& Guimarães, 1988). The hybrid rice program in Brazil is based on the traditional three line method (Lin \& Yuan, 1980) and the procedure involves crossing the "A" line, possessing WA cytoplasm that confers male sterility and the " $\mathrm{R}$ " line containing the restorer gene for fertility. A 
" $\mathrm{B}$ " maintainer line is utilized to produce seeds for the "A" line. The male sterile lines IR58025A and IR62829A introduced from IRRI in 1992, and 046I, developed in Brazil with large stigma traits were found to be more effective and most widely utilized in the Brazilian hybrid rice program (Guimarães \& Cutrim, 1999).

The hybrids are generally superior to their parents in grain yield due to heterosis, adaptability and tolerance to abiotic stresses. However, they are subjected to diseases and pests, mainly rice blast caused by Pyricularia grisea (Cooke) Sacc. Blast epidemics in different parts of China were related to the monoculture of a single hybrid over extensive areas and the changes in virulence frequency of the prevailing races of P. grisea (Mew et al., 1988). The success of hybrids is mainly dependent on choosing parents that are well-adapted to local conditions and resistant to diseases. The results from yield trials in Brazil showed that some hybrids were promising and with yields superior to commercial rice cultivars. In the tests conducted during the 1994/95 growing season, in the State of Rio Grande do Sul, the best hybrid yielded $45 \%$ more than the commercial cultivar used as a control (Guimarães \& Cutrim, 1999). The parental lines and rice hybrids in China have been selected for resistance to diseases and insect pests (Reddy et al., 1998). However, these hybrids had poor yields when tested under tropical conditions because of susceptibility to diseases (Virmani, 1998). Disease management is one of the important factors in seed production and the development of blast resistant parental lines is the most economic means of control. There is very little information on the performance of hybrids and their parents in relation to rice blast disease and the nature of resistance. In an earlier investigation on partial resistance to blast utilizing five hybrids, all showed an intermediate level of resistance compared with lines " $A$ " and " $R$ " to a specific race IB-9. In tests conducted with 79 " $R$ " lines at eight different locations in the National Rice Blast nursery in Brazil, 46.8\% showed vertical resistance. However, the reactions varied at different test locations depending on the occurence of matching races to the vertical genes in these lines (Guimarães et al., 2000). This study was further extended to include two distinct A lines derived from WA cytoplasm, and several restorers exhibiting different degrees of resistance, in order to study the performance of hybrids under conditions of artificial inoculation with virulent pathotypes and in the blast nursery under heavy disease pressure.

\section{MATERIAL AND METHODS}

Isolates virulent to restorers were selected by utilizing six isolates of $P$. grisea collected from four irrigated rice cultivars (Metica-1, EPAGRI-108, CICA-8 and Tetep) from field trials in the experimental stations of Embrapa Rice \& Beans, Santo Antônio de Goiás, GO; and commercial fields in the State of Tocantins. Single conidial isolates were established from sporulating lesions and stock cultivars were maintained on filter paper disks in sterilized butter paper bags at $4{ }^{\circ} \mathrm{C} \pm 1{ }^{\circ} \mathrm{C}$ in the refrigerator.
Sixty-four rice genotypes including 39 restorers, four hybrids (H981003, H981004, H981005, H981007), three male sterile lines (046I, IR58025A, IR68281A), two maintainers (IR 58025B, IR68281B) and eight international differentials (Caloro, Dular, Kanto 51, NP125, Raminad Str 3, Sha io são, Usen, Zenith), five near isogenic lines (C101LAC, C101A51, C104PKT, C101PKT, C105TTP4L23) of CO-39 and three commercial rice cultivars were used for evaluating the virulence of the selected isolates. The commercial rice cultivars and some genotypes possess unknown resistance genes whereas in near isogenic lines (NIL's) blast resistance was conferred by known independent dominant genes. The virulence frequencies expressed in percentages were based on the compatible reactions on 64 genotypes. Race identification was made using the eight standard international differentials.

The test material was planted in plastic trays $(15 \times 30$ $\mathrm{cm}$ ) containing $3 \mathrm{~kg}$ of soil fertilized with NPK (5 g of 5-30$15+\mathrm{Zn}, 3 \mathrm{~g}$ of ammonium sulfate per $3 \mathrm{~kg}$ of soil). Ten to 12 seeds of 16 genotypes in $5.0 \mathrm{~cm}$ rows were planted in each tray.

For sporulation, the isolates were grown on rice polish agar in Petri dishes and incubated at $25{ }^{\circ} \mathrm{C}$ for seven days. Inoculum was prepared as described earlier (Prabhu et al., 1992) and concentration was adjusted to $3 \times 10^{5}$ conidia per $\mathrm{ml}$. Twenty-two day old plants with three fully expanded leaves were inoculated by spraying with aqueous spore suspension on the leaves using an atomizer connected to an air compressor, until run-off. Inoculated plants were incubated in moist chamber for $24 \mathrm{~h}$ at 20 to $24{ }^{\circ} \mathrm{C}$ after which they were kept in the greenhouse at temperatures ranging from 25 ${ }^{\circ} \mathrm{C}-28^{\circ} \mathrm{C}$.

Disease reaction was assessed nine days after inoculation following the visual rating scale varying from 0 to 9 according to the standard evaluation system (International Rice Research Institute, 1988). The isolates that induced typical sporulating lesions were considered virulent or compatible (4-9) and necrotic non-sporulating lesions as incompatible (0-3). Inoculation tests were repeated twice and the tests that gave consistent and uniform reactions were utilized for statistical analysis.

Partial resistance (PR) in the hybrids and their parents was analyzed, utilizing two virulent isolates of $P$. grisea, in two separate inoculation tests conducted under controlled greenhouse conditions. In one experiment 'A' line 046I, 17 ' $R$ ' lines and their hybrids were assessed. In another experiment, 'A' line IR58025A, 22 'R' lines and their hybrids were assessed. One line of each test material was sown in separate trays following the randomized block design with three replications. The same inoculation and evaluation procedures as described above were employed.

The number of sporulating lesions per $\mathrm{cm}^{2}$ of leaf area and disease severity based on the percentage of leaf area affected was analyzed. The sporulating lesion number was determined based on $5.0 \mathrm{~cm}$ of the leaf area of 20 seedlings per tray, seven days after inoculation. The infected leaves 


\section{A.S. Prabhu et al.}

were counted in a sample of 50 seedlings per genotype five days after inoculation. The number of leaves with at least one sporulating lesion was considered. At nine days after inoculation, the percentage of leaf area infected was measured according to Notteghem (1981) in a sample of 30 seedlings per replicate, selected at random. For the variance analysis the lesion number and disease severity data were transformed to $\sqrt{x+0.5}$ and arcsine $\sqrt{x}$, respectively. Hybrids and thei parents were tested in the National Blast Nursery (Viveiro Nacional de Brusone-VNB) conducted at Palmital experimental Station of Embrapa Rice \& Beans, located in the municipality of Brazabrantes. The disease assessment was done using the standard 0-9 scale.

\section{RESULTS AND DISCUSSION}

The pathotypes identified based on eight international differentials and the virulence frequency of the six isolates on 63 genotypes are shown in Table 1. The six isolates pertain to five standard international races IG-1, IC-1, IA-77, ID-14 and IB-45. The races ID-14 and IB-45 are very common in the farmers' fields of Metica-1 and EPAGRI 108, respectively. The virulence frequency among the isolates ranged from 11.1 to $71.4 \%$. The isolates Py 506-Tetep $\mathrm{L}_{3,1}$ retrieved from the cultivar Tetep and Py $1648-\mathrm{L}_{3.2}$ were selected for the determination of partial resistance in the hybrids.

Leaf blast reaction of restorers and 17 hybrids developed with CMS line 046I, in the blast nursery and in inoculation tests with two isolates are shown in Table 2.

Of 17 restorers only two exhibited resistant reaction type 3, while 15 exhibited susceptible reactions (5 to 9) in the blast nursery. The CMS line 046I utilized as a common female parent showed the highly susceptible reaction type 8 while the reaction of hybrids ranged from 5 to 8 . Even the hybrids H981018 and H981019, which included the resistant male parent showed susceptible reactions. These two hybrids and the male parents also exhibited highly resistant reaction to both races in inoculation tests. Twelve restorers were resistant to the isolate Py 506 and six to the isolate Py 1648. However, six restorers showed resistant reaction and four susceptible reactions to both isolates. All hybrids developed with resistant male parents showed highly resistant reaction to individual isolates when inoculated separately.
TABLE 2 - Leaf blast reaction of parents and rice (Oryza sativa) hybrids developed using CMS line 046I as female parent in the rice blast nursery and greenhouse inoculations with two isolates of Pyricularia grisea

\begin{tabular}{|c|c|c|c|}
\hline \multirow{3}{*}{$\begin{array}{l}\text { Parent and } \\
\text { hybrid }\end{array}$} & \multicolumn{3}{|c|}{ Disease score $^{1}$} \\
\hline & \multirow{2}{*}{$\begin{array}{c}\text { Blast } \\
\text { nursery }\end{array}$} & \multicolumn{2}{|c|}{ Isolates } \\
\hline & & Py 506 - Tetep L 3.1 & Py $1648-\mathrm{L}_{3.2}$ \\
\hline $046 \mathrm{I} / 25 \mathrm{C}^{2}$ & $8 / 6^{4}$ & $4 / 0$ & $5 / 0$ \\
\hline H981003 ${ }^{3}$ & - & 0 & 0 \\
\hline $046 \mathrm{I} / 27 \mathrm{C}$ & $8 / 6$ & $4 / 0$ & $5 / 0$ \\
\hline H981004 & 5 & 0 & 0 \\
\hline $046 \mathrm{I} / 287$ & $8 / 9$ & $4 / 0$ & $5 / 7$ \\
\hline H981005 & 7 & 0 & 7 \\
\hline $046 \mathrm{I} / 28 \mathrm{~W}$ & $8 / 6$ & $4 / 0$ & $5 / 0$ \\
\hline H981007 & 6 & 0 & 0 \\
\hline $046 \mathrm{I} / 286$ & $8 / 9$ & $4 / 0$ & $5 / 7$ \\
\hline H981010 & 7 & 0 & 5 \\
\hline $046 \mathrm{I} / 290$ & $8 / 6$ & $4 / 4$ & $5 / 4$ \\
\hline H981012 & 6 & 4 & 4 \\
\hline 046I/2BJ & $8 / 3$ & $4 / 0$ & $5 / 0$ \\
\hline H981018 & 5 & 0 & 0 \\
\hline $046 \mathrm{I} / 2 \mathrm{C} 0$ & $8 / 3$ & $4 / 0$ & $5 / 0$ \\
\hline H981019 & 5 & 0 & 0 \\
\hline $046 \mathrm{I} / 259$ & $8 / 8$ & $4 / 5$ & $5 / 7$ \\
\hline H981021 & 7 & 4 & 5 \\
\hline $046 \mathrm{I} / 2 \mathrm{~A} 6$ & $8 / 8$ & $4 / 0$ & $5 / 4$ \\
\hline H981026 & 6 & 0 & 4 \\
\hline $046 \mathrm{I} / 23 \mathrm{H}$ & $8 / 8$ & $4 / 0$ & $5 / 7$ \\
\hline H981028 & 7 & 0 & 5 \\
\hline $046 \mathrm{I} / 29 \mathrm{U}$ & $8 / 9$ & $4 / 4$ & $5 / 7$ \\
\hline H981030 & 7 & 4 & 5 \\
\hline $046 \mathrm{I} / 2 \mathrm{AG}$ & $8 / 8$ & $4 / 5$ & $5 / 7$ \\
\hline H981031 & 7 & 4 & 7 \\
\hline $046 \mathrm{I} / 26 \mathrm{~A}$ & $8 / 8$ & $4 / 4$ & $5 / 7$ \\
\hline H981033 & 8 & 4 & 5 \\
\hline $046 \mathrm{I} / 24 \mathrm{~A}$ & $8 / 6$ & $4 / 0$ & $5 / 4$ \\
\hline H971050 & 6 & 0 & 4 \\
\hline $046 \mathrm{I} / 270$ & $8 / 6$ & $4 / 0$ & $5 / 0$ \\
\hline H981051 & 5 & 0 & 0 \\
\hline $046 \mathrm{I} / 24 \mathrm{~F}$ & $8 / 5$ & $4 / 0$ & $5 / 5$ \\
\hline H981085 & 6 & 0 & 5 \\
\hline
\end{tabular}

${ }^{1}$ Standard 0-9 scale, where 0-3 = resistant and 4-9= susceptible reactions; ${ }^{2} \mathrm{CMS}$ line/male parent; ${ }^{3}$ hybrid; ${ }^{4}$ disease score of CMS line/male parent.

TABLE 1 - Pathotypes and virulence frequency of six Pyricularia grisea isolates obtained from irrigated rice (Oryza sativa) cultivars

\begin{tabular}{|c|c|c|c|c|c|}
\hline Isolate & Year & Origin & Location & Patotype $^{1}$ & $\begin{array}{c}\text { Virulence } \\
\text { frequency }(\%)^{2}\end{array}$ \\
\hline Py 409-Cica $8 \mathrm{~L}_{4.2}$ & 1994 & Cica-8 & IRBN - Palmital/Go & IG-1 & 11.1 \\
\hline Py 506-Tetep $\mathrm{L}_{3.1}$ & 1995 & Tetep & VNB - Capivara/Go & IC-1 & 71.4 \\
\hline Py $1125-41-\mathrm{L}_{1.3}$ & 1998 & Metica-1 & Lagoa da Confusão/To & IA-77 & 42.8 \\
\hline Py $1014-8-L_{1.7}$ & 1998 & Metica-1 & Lagoa da Confusão/To & ID-14 & 42.8 \\
\hline Py $1663-\mathrm{L}_{1.1}$ & 1999 & Epagri-108 & Lagoa da Confusão/To & IB-45 & 50.0 \\
\hline Py $1648-L_{3.2}$ & 1999 & Epagri-108 & Lagoa da Confusão/To & IB-45 & 47.6 \\
\hline
\end{tabular}

\footnotetext{
${ }^{1}$ Identified based on reaction on eight international differentials.
${ }^{2}$ Virulence frequency determined based on the number of compatible isolates on 63 genotypes.
} 
According to the results of inoculation tests of restorers and 22 hybrids developed with CMS line IR58025A (Table 3 ), the parents as well as hybrids showed susceptible leaf blast reactions ranging from 5 to 9 under heavy disease pressure in the blast nursery. In inoculation tests, the disease scores of CMS line were 7 and 4 for isolates Py 1648 and Py 506, respectively, indicating that the former was more aggressive than the latter. Of seven hybrids in which the male parents exhibited resistant reaction to the isolate Py 506, four were resistant and three showed susceptible reactions. Of 11 hybrids derived from male parents resistant to the isolate Py 1648, seven and four showed resistant and susceptible reactions, respectively. The effectiveness of the resistance gene in the hybrids varied with different isolates.

The performance of the hybrids in the blast nursery was variable depending on the degree of susceptibility or resistance of the parents. When one of the parents was resistant, hybrids in general showed complete vertical resistance even under high disease pressure. These results are in agreement with those obtained in the earlier investigations. However, in the case of two hybrids (H981045, H981048) even when the male parent was resistant, the hybrids showed susceptible reactions. The disease scores were low, however, indicating moderate susceptibility. Even in inoculations with individual races similar results were obtained. Blast resistance, in general, is monogenic or oligogenic (Mackill \& Bonman, 1992; Filippi \& Prabhu, 1996). Genes for blast resistance are dominant and segregate independently in most donors (Yu et al., 1987). Furthermore, there is sufficient evidence to support THE gene for gene hypothesis $(\mathrm{Ou}, 1985)$. The $\mathrm{F}_{1}$ hybrid is expected to exhibit complete resistance if one of the parents in the cross is resistant to a given pathotype. However, the susceptible reaction of $F_{1}$ could be attributed to recessive gene control of blast resistance in some of the restorers. In inheritance studies utilizing three isolates of $P$. grisea the resistance in improved rice cultivar IR 54 has been shown to be controlled by one recessive pair of genes (Yu et al., 1987).

The CMS line 046I was moderately susceptible to both isolates whereas IR 58025A was highly susceptible to one isolate and moderately susceptible to another isolate (Tables 2 and 3). The two main problem in using the CMS lines are that grain yields attained a ceiling and the lack of variability in the available male sterile sources, because $85 \%$ of the lines were derived from cytoplasm WA (Yuan et al., 1994). This kind of uniformity in cytoplasm can result in disease epidemics such as Helminthosporium maidis Nisik \& Miy. that occurred in maize (Zea mays L.) hybrids with cytoplasm T. However, it is possible to overcome this problem by diversification of cytoplasmic male sterile lines by inter or intraspecific hybridization, mutation and other molecular methods (Brar et al., 1998).

The level of partial resistance in hybrids in which both parents showed susceptible reaction to two isolates was examined. The analysis of variance for both lesion number and disease severity showed isolate $\mathrm{x}$ genotype interaction
TABLE 3 - Leaf blast reaction of parents and rice (Oryza sativa) hybrids developed using CMS line IR58025A in the rice blast nursery and greenhouse inoculations with two isolates of Pyricularia grisea

\begin{tabular}{|c|c|c|c|}
\hline \multirow{3}{*}{$\begin{array}{l}\text { Parent and } \\
\text { hybrid }\end{array}$} & \multicolumn{3}{|c|}{ Disease score $^{1}$} \\
\hline & \multirow{2}{*}{$\begin{array}{c}\text { Blast } \\
\text { nursery }\end{array}$} & \multicolumn{2}{|c|}{\begin{tabular}{|l} 
Isolates \\
\end{tabular}} \\
\hline & & Py 506 - Tetep $\mathrm{L}_{3.1}$ & Py $1648-L_{3.2}$ \\
\hline IR58025A/2B3 ${ }^{2}$ & $9 / 9^{4}$ & $4 / 1$ & $7 / 9$ \\
\hline $\mathrm{H} 981035^{3}$ & 9 & 0 & 7 \\
\hline IR58025A/0X1 & $9 / 6$ & $4 / 7$ & $7 / 5$ \\
\hline H981036 & 9 & 7 & 7 \\
\hline IR58025A/16Z & $9 / 5$ & $4 / 5$ & $7 / 3$ \\
\hline H981037 & 6 & 5 & 0 \\
\hline IR58025A/191 & $9 / 8$ & $4 / 5$ & $7 / 7$ \\
\hline H981038 & 8 & 5 & 7 \\
\hline IR58025A/27U & $9 / 4$ & $4 / 1$ & $7 / 0$ \\
\hline H981039 & 6 & 3 & 0 \\
\hline IR58025A/2BW & $9 / 9$ & $4 / 5$ & $7 / 7$ \\
\hline H981041 & 9 & 7 & 7 \\
\hline IR $58025 \mathrm{~A} / 10 \mathrm{~N}$ & $9 / 9$ & $4 / 0$ & $7 / 7$ \\
\hline H981045 & 9 & 5 & 7 \\
\hline IR58025A/2BV & $9 / 9$ & $4 / 0$ & $7 / 7$ \\
\hline H981048 & 9 & 7 & 9 \\
\hline IR58025A/26M & $9 / 7$ & $4 / 7$ & $7 / 0$ \\
\hline H981049 & 9 & 5 & 0 \\
\hline IR58025A/28Y & $9 / 6$ & $4 / 4$ & $7 / 0$ \\
\hline H981050 & 8 & 5 & 0 \\
\hline IR58025A/0Z0 & $9 /-$ & $4 / 7$ & $7 /-$ \\
\hline H981051 & 8 & 4 & 2 \\
\hline IR58025A/215 & $9 / 5$ & $4 / 7$ & $7 / 0$ \\
\hline H981052 & 5 & 5 & 0 \\
\hline IR58025A/22K & $9 / 5$ & $4 / 7$ & $7 / 0$ \\
\hline H981053 & 5 & 7 & 0 \\
\hline IR58025A/25Q & $9 / 5$ & $4 / 7$ & $7 / 0$ \\
\hline H981054 & 6 & 4 & 0 \\
\hline IR58025A/2BC & $9 / 7$ & $4 / 5$ & $7 / 0$ \\
\hline H971055 & 6 & 4 & 4 \\
\hline IR58025A/11N & $9 / 7$ & $4 / 0$ & $7 / 0$ \\
\hline H981056 & 6 & 5 & 4 \\
\hline IR58025A/2BQ & $9 / 9$ & $4 / 7$ & $7 / 9$ \\
\hline H971035 & 9 & 5 & 9 \\
\hline IR58025A/277 & $9 / 8$ & $4 / 4$ & $7 / 7$ \\
\hline H971040 & 9 & 5 & 7 \\
\hline IR58025A/2BF & $9 / 6$ & $4 / 5$ & $7 / 0$ \\
\hline H981064 & 7 & 7 & 5 \\
\hline IR58025A/2CG & $9 / 5$ & $4 / 0$ & $7 / 4$ \\
\hline H971065 & 8 & 0 & 4 \\
\hline IR58025A/24A & $9 / 6$ & $4 / 2$ & $7 / 7$ \\
\hline H981108 & 7 & 3 & 7 \\
\hline IR58025A/273 & $9 / 7$ & $4 / 4$ & $7 / 0$ \\
\hline H981112 & 8 & 4 & 4 \\
\hline
\end{tabular}

${ }^{1}$ Standard 0-9 scale, where 0-3 = resistant and 4-9= susceptible reactions; ${ }^{2}$ male parent; ${ }^{3}$ hybrid; disease score of CMS line/male parent. 
TABLE 4 - Analysis of variance for leaf blast severity and sporulating lesion number of $\mathrm{F}_{1}$ rice (Oryza sativa) hybrids and their parents

\begin{tabular}{|c|c|c|c|c|c|c|c|}
\hline \multirow[b]{2}{*}{ Source } & \multirow{2}{*}{$\begin{array}{l}\text { Degrees of } \\
\text { freedom }\end{array}$} & \multicolumn{2}{|c|}{ Sum of squares } & \multicolumn{2}{|c|}{ Mean square } & \multicolumn{2}{|c|}{ F value $^{1}$} \\
\hline & & Severity & $\begin{array}{c}\text { Lesion } \\
\text { number } / \mathrm{cm}^{2}\end{array}$ & Severity & $\begin{array}{c}\text { Lesion } \\
\text { number } / \mathrm{cm}^{2}\end{array}$ & Severity & $\begin{array}{c}\text { Lesion } \\
\text { number } / \mathrm{cm}^{2}\end{array}$ \\
\hline Replication & 2 & 0.034 & 0.297 & 0.017 & 0.148 & 0.80 & 1.17 \\
\hline Isolates & 1 & 0.275 & 0.653 & 0.275 & 0.653 & 13.14 & 5.17 \\
\hline Error (a) & 2 & 0.042 & 0.253 & 0.021 & 0.126 & - & - \\
\hline Genotypes & 23 & 7.938 & 21.573 & 0.345 & 0.938 & $10.69^{* *}$ & $14.46^{* *}$ \\
\hline Isolates $\mathrm{x}$ genotypes & 23 & 1.761 & 3.240 & 0.077 & 0.141 & $2.37^{*}$ & $2.17 *$ \\
\hline Error (b) & 92 & 2.968 & 5.964 & 0.032 & 0.065 & - & - \\
\hline
\end{tabular}

(Table 4). The orthogonal partitioning of the data according to hybrids derived from CMS line 046I and IR58025A (Table 5). The mean disease severity as well as the lesion number of the male parents and hybrids developed using A line 046I was significantly lower than the mean of the hybrids developed with A line IR58025A. The results of inoculation tests were similar with both isolates. Considering the grand mean, the disease severity and lesion number of male parents and hybrids did not differ for the isolate Py 506, and differed significantly for the isolate Py 1648.

The number of sporulating lesions per unit area was highly correlated with disease severity regardless of the isolate (Figure 1). Even though the correlation between incidence measured as the number of leaves with sporulating lesions and severity was significant $(\mathrm{r}=0.66 ; \mathrm{P} \leq 0.05)$, it was low. Interaction between genotypes and isolates was not evident.
For this reason, it was not utilized as a parameter for the evaluation of partial resistance (PR). The number of leaves exhibiting at least one sporulating lesion was highly correlated with disease severity (Roumen, 1992). The low correlation obtained in this study could be attributed to the 3-leaf stage of the plants at which inoculations were performed. The treatment differences and the interactions were less clear when expressed as incidence and were considered to be inadequate parameters for PR assessment.

The effectiveness of major gene resistance is lost within a few years after the release of new cultivars, specially in tropical conditions (Ou, 1985). The chance that a pre-existing pathotype of low frequency will come in contact with a major gene, increases with rice cultivation in extensive areas, which may result in the rapid breakdown of resistance. In general, resistance is lost in one or two years as was the case of EPAGRI

TABLE 5 - Leaf blast severity and sporulating lesion number of $F_{1}$ rice (Oryza sativa) hybrids and their parents to two isolates of Pyricularia grisea

\begin{tabular}{|c|c|c|c|c|c|c|c|c|}
\hline \multirow{4}{*}{$\begin{array}{l}\text { Female } \\
\text { parent }\end{array}$} & \multicolumn{8}{|c|}{ Pyricularia grisea Isolates } \\
\hline & \multicolumn{4}{|c|}{ Py 506 - Tetep $\mathrm{L}_{3.1}$} & \multicolumn{4}{|c|}{ Py $1648-\mathrm{L}_{3.2}$} \\
\hline & \multicolumn{2}{|c|}{ Severity $(\%)^{1}$} & \multicolumn{2}{|c|}{ Lesion number/sq.cm² } & \multicolumn{2}{|c|}{ Severity (\%) } & \multicolumn{2}{|c|}{ Lesion number $/ \mathrm{cm}^{2}$} \\
\hline & MaleParent & Hybrid & Male Parent & Hybrid & Male Parent & Hybrid & Male Parent & Hybrid \\
\hline \multirow[t]{6}{*}{$046 \mathrm{I}^{5}$} & 0.85 & 3.61 & 0.58 & 1.80 & 3.50 & 2.84 & 3.73 & 2.93 \\
\hline & 5.53 & 2.93 & 5.70 & 1.70 & 47.23 & 21.23 & 16.9 & 7.80 \\
\hline & 9.43 & 5.53 & 5.17 & 3.41 & 45.66 & 18.10 & 17.4 & 7.97 \\
\hline & 9.66 & 9.56 & 4.03 & 4.83 & 25.60 & 30.73 & 9.4 & 13.40 \\
\hline & 3.76 & 5.80 & 1.87 & 4.47 & 33.03 & 16.06 & 14.2 & 6.43 \\
\hline & Mean $=5.8 \mathrm{~A}^{3}$ & Mean $=5.4 \mathrm{~A}$ & Mean $=3.4 \mathrm{~A}$ & Mean $=3.2 \mathrm{~A}$ & Mean $=31.0 \mathrm{~A}$ & Mean $=17.8 \mathrm{~A}$ & Mean $=12.3 \mathrm{~A}$ & Mean $=7.7 \mathrm{~A}$ \\
\hline \multirow[t]{8}{*}{ IR58025 $A^{6}$} & 28.0 & 59.67 & 16.73 & 23.63 & 47.40 & 29.57 & 20.17 & 18.27 \\
\hline & 68.13 & 68.5 & 28.13 & 30.57 & 56.37 & 33.87 & 25.33 & 18.73 \\
\hline & 11.73 & 19.5 & 15.83 & 14.47 & 27.90 & 27.13 & 11.57 & 13.07 \\
\hline & 50.17 & 70.17 & 21.47 & 32.73 & 58.50 & 45.23 & 26.33 & 22.77 \\
\hline & 69.2 & 52.80 & 30.27 & 20.23 & 64.93 & 55.3 & 28.93 & 25.23 \\
\hline & 37.5 & 33.47 & 20.90 & 17.47 & 41.10 & 45.17 & 19.00 & 20.90 \\
\hline & Mean $=44.1 \mathrm{~B}$ & Mean $=50.7 \mathrm{~B}$ & Mean $=22.2 B$ & Mean $=23.1 \mathrm{~B}$ & Mean $=59.2 B$ & Mean $=39.3 \mathrm{~B}$ & Mean $=21.8 \mathrm{~B}$ & Mean $=19.8 \mathrm{~B}$ \\
\hline & Mean $=26.7 \mathrm{a}^{4}$ & Mean $=30.1 \mathrm{a}$ & Mean $=13.7 \mathrm{a}$ & Mean $=14.1 \mathrm{a}$ & Mean $=46.3 \mathrm{a}$ & Mean $=29.5 b$ & Mean $=17.5 \mathrm{a}$ & Mean $=14.31 \mathrm{~b}$ \\
\hline
\end{tabular}

${ }^{1}$ Data were transformed to arcsine; ${ }^{2}$ Lesion numbers were transformed to $\sqrt{x+0.5} ;{ }^{3}$ Means followed by the same capital letters do not differ significantly between the first and second group of male and hybrids represented by common female parental A lines $046 \mathrm{I}$ and IR58025A, respectively; ${ }^{4} \mathrm{Grand}$ means of male parents and hybrids followed by small letters do not differ significantly between male parents and hybrids.

${ }^{5}$ Severity of female parent $046 \mathrm{I}=2$ for Py $506-$ Tetep $\mathrm{L}_{31}$ and Py $1648-\mathrm{L}_{32}=4.63$; lesion number of female parent $046 \mathrm{I}=1.9$ for Py $506-$ Tetep $\mathrm{L}_{3,}$ and Py 1648 $-\mathrm{L}_{3.2}$ and 4.6. ${ }^{6}$ Severity of female parent IR58025A=30.33 for Py $506-$ Tetep $\mathrm{L}_{3.1}$ and Py $1648-\mathrm{L}_{3.2}=25.53$; lesion number of female parent IR58025A $=10.3$ for Py 506 - Tetep $\mathrm{L}_{3.1}$ and Py $\left.1648=10.3\right)$. 


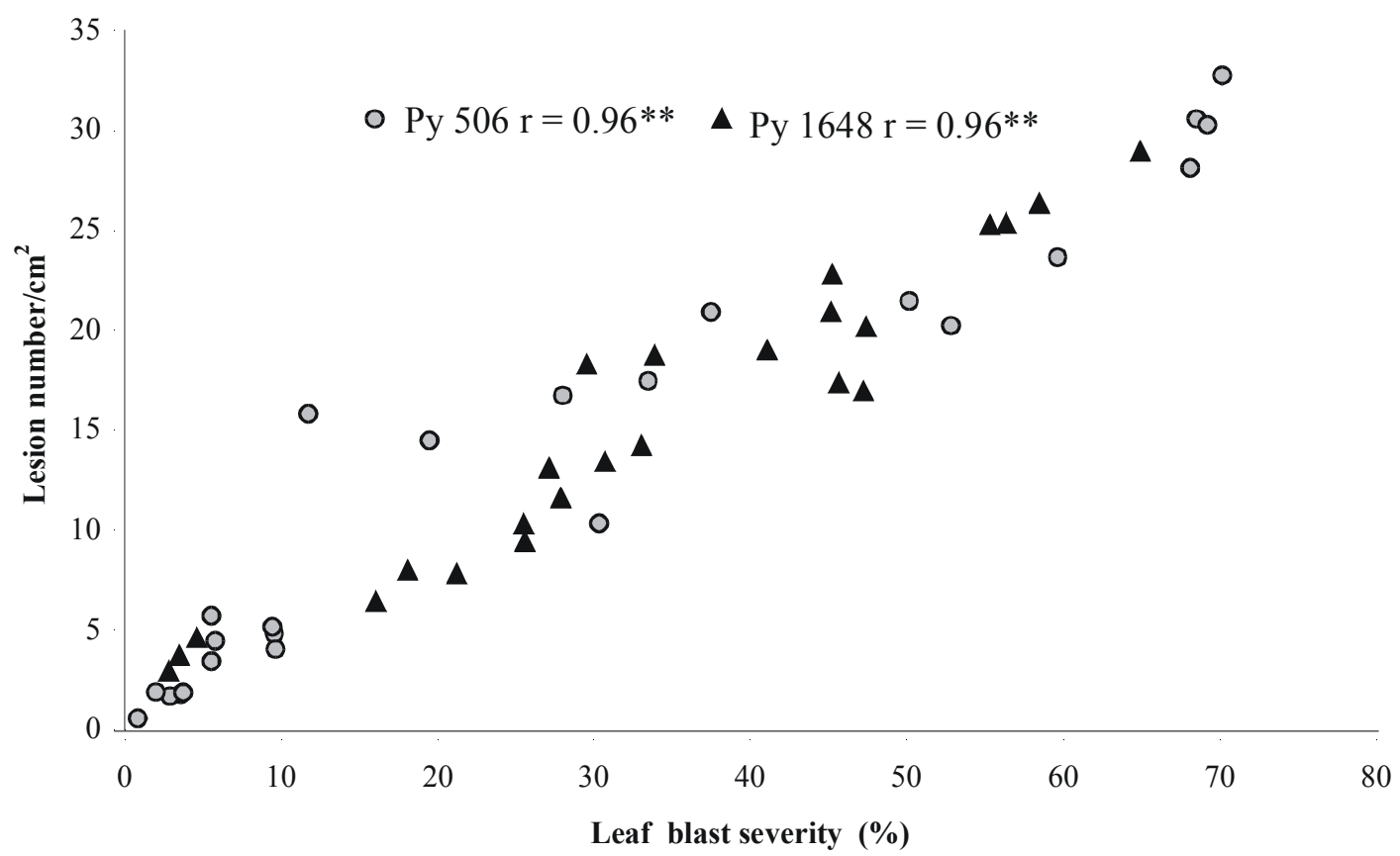

FIG. 1 - Relationship between leaf blast severity and lesion number per square centimeter of the leaf area affected in artificial inoculation test under greenhouse conditions [each data point represents the mean value of one rice (Oryza sativa) genotype].

108 in the State of Tocantins (Prabhu \& Filippi, 1999). It is possible that blast epidemics may also occur when hybrid rice with vertical resistance is released and cultivated in extensive areas.

Partial resistance characterized by susceptible infection type is considered durable because its resistance is of a nonspecific nature (Parlevliet \& Ommeren, 1975). However, it is subject to changes in environmental conditions (Ou, 1985). In the field, a mixture of races is encountered and the partial resistance assessment is hindered by the epistatic effects of the major genes. Evaluation of PR utilizing one or more components of resistance with a virulent pathotype is often indicated as an appropriate approach to determine the differences among cultivars, since PR is race non-specific. It is not certain, however, that a single virulent race represents all virulent races in relation to the determination of PR (Roumen, 1992). In the present study, interaction between virulent pathotypes and rice genotypes for PR has been observed, indicating the race specific nature. These results are in accord with earlier reports of race specific PR (Bonman et al., 1987). The interaction suggests a gene for gene relationship in a polygenic system with relatively small effects of each gene as postulated by Parlevliet \& Zadoks (1977). Screening of hybrids using more than one virulent pathotypes would facilitate better assessment of race specific nature and the level of partial resistance. The results in the present study showed that it cannot be generalized that hybrids exhibit intermediate levels of partial resistance compared to parents. However, by incorporation of major genes in the parents with an adequate level of partial resistance, it should be possible to produce desirable hybrids.

\section{LITERATURE CITED}

BONMAN, J.M., BANDONG, J.M., LEE, Y.H., LEE, E.J. \& VALENT, B. Race specific partial resistance to blast in temperate Japonica rice cultivars. Plant Disease 73:496-499. 1987.

BRAR, D.R., ZHU, Y.G., AHMED, M.I., JACHUK, P.J. \& VIRMANI, S.S. Diversifying the CMS system to improve the sustainability of hybrid rice technology. In: Virmani, S.S., Siddiq, E.A. \& Muralidharan, K. (Eds.). Advances in Hybrid Rice Technology. Manila. IRRI. 1998. pp.129-146.

FILIPPI, M.C. \& PRABHU, AS. Inheritance of blast resistance in rice to two Pyricularia grisea races, IB-1 and IB-9. Brazilian Journal of Genetics 19:599-604. 1996.

GUIMARÃES E.P., PRABHU, A.S., FILIPPI, M.C., SILVA, S.A. Resistance to blast in hybrid rice. In: Tharreau, D., Lebrun, M.H., Talbot, N.J., Notteghem, J.L. (Eds.). Advances in Rice Blast Research. Dordrecht: Kluwer Academic Publishers. 2000. pp.129-136.

GUIMARÃES, E.P. \& CUTRIM, V. dos A. Arroz híbrido na Embrapa Arroz e Feijão, próximo à realidade. Anais, $6^{\mathrm{a}}$ Reunião Nacional de Pesquisa de Arroz, Goiânia, GO. 1999. pp.37-53.

GUIMARÃES, E.P., CUTRIM, V. dos A. \& MENDONÇA, J.A. Developing hybrid rice in Brazil: methodology, highlights, and prospects. In: Virmani, S.S., Siddiq, E.A. \& Muralidharan, K. (Eds.). Advances in Hybrid Rice Technology. Manila. IRRI. 1998. pp.379-387.

INTERNATIONAL RICE RESEARCH INSTITUTE. Standard Evaluation System for Rice. Manila. 1988.

LIN, S.C. \& YUAN, I.P. Hybrid rice breeding in China. In: INTERNATIONAL RICE RESEARCH INSTITUTE. Innovative Approaches to Rice Breeding. Los Baños. 1980. pp.33-51.

MACKILL, D.J. \& BONMAN, J.M. Inheritance of blast resistance 


\section{A.S. Prabhu et al.}

in near isogenic lines of rice. Phytopathology 82:746-749. 1992.

MAO, C.X., VIRMANI, S.S. \& KUMAR, I. Technological innovations to lower costs of hybrid rice seed production. In: Virmani, S.S., Siddiq, E.A. \& Muralidharan, K. (Eds.). Advances in Hybrid Rice Technology. Manila. IRRI. 1998. pp.111-128.

MEW, T.W., WANG, F.M., WU, J.T., LIN, K.R. \& KHUSH, Disease and insect resistance in hybrid rice. In: Proceedings, International Symposium on Hybrid Rice, Manila, Filipinas. 1988. pp.189-200.

NOTTEGHEM, J.L. Cooperative experiment on horizontal resistance to rice blast. In: INTERNATIONAL RICE RESEARCH INSTITUTE. Blast and Upland Rice: Report and Recommendations From the Meeting for International Collaboration in Upland Rice Improvement. Los Baños. 1981. pp.43-51.

OU, S.H. Rice Disease. $2^{\text {nd }}$ ed. Kew. Commonwealth Mycological Institute. 1985.

PARLEVLIET, J.E. \& OMMEREN, V.A. Partial resistance of barley to leaf rust Puccinia hordei. II. Relationship between field trials, microplot tests and latent period. Euphytica 24:223-303. 1975.

PARLEVLIET, J.E. \& ZADOKS, J.C. The integrated concept of disease resistance: A new view including horizontal and vertical resistance in plants. Euphytica 26:5-21. 1977.

PRABHU, A.S. \& FILIPPI, M.C. Padrão de virulência dos isolados de Pyricularia grisea provenientes da cultivar EPAGRI 108, de lavouras de arroz. Fitopatologia Brasileira 24:319. 1999. (Resumo).

PRABHU, A.S., FILIPPI, M.C. \& CASTRO, N. Pathogenic variation among isolates of Pyricularia oryzae affecting rice, wheat and grasses in Brazil. Tropical Pest Management 38:367-371. 1992.

REDDY, A.P.K., KRISHNAIAH, K., ZHANG, Z.T. \& SHEN, Y. Managing vulnerability of hybrid rice to biotic stresses in China and India. In: Virmani, S.S., Siddiq, E.A. \& Muralidharan, K. (Eds.). Advances in Hybrid Rice Technology. Manila. IRRI. 1998. pp.147-156.

ROUMEN, E.C. Small differential interactions for partial resistance in rice cultivars to virulent isolates of the blast pathogen. Euphytica 64:143-148. 1992.

TAILLEBOIS, J. Une nouvelle perspective pour la production de semences hybrides $\mathrm{F}_{1}$ : le transfert des caractères d'allogamie de l'espèce $O$. longistaminata $\mathrm{A}$. Chev. à l'espèce $O$. sativa L. Agron. Trop. 38:303-307. 1983.

TAILLEBOIS, J. \& GUIMARÃES, E.P. Improving outcrossing rate in rice (Oryza sativa L.). In: Hybrid Rice. Manila. International Rice Research Institute. 1988. pp.175-180.

VIRMANI, S.S. Hybrid rice research and development in the tropics. In: Virmani, S.S., Siddiq, E.A. \& Muralidharan, K. (Eds.). Advances in Hybrid Rice Technology. Manila. IRRI. 1998. pp.35-50.

YU, Z.H., MACKILL, D.J. \& BONMAN, J.M. Inheritance of resistance to blast in some traditional and improved rice cultivars. Phytopathology 77:323-326. 1987.

YUAN, L.P., YANG, Z.Y. \& YANG, J.B. Hybrid rice in China. In: Virmani, S.S. (Ed.) Hybrid Rice Technology: New Developments and Future Prospects. Manila. International Rice Research Institute. 1994. pp.143-147. 